\title{
ACID MINE DRAINAGE MITIGATION: A REVIEW
}

\author{
DANIEL LAZO* \\ https://orcid.org/0000-0003-1757-5444 \\ Western Australian School of Mines, Curtin University, Australia
}

Recibido: 16 de agosto / Aprobado: 28 de agosto del 2020

doi: https://doi.org/10.26439/ing.ind2020.n039.4917

\begin{abstract}
Acid mine drainage (AMD) or acid rock drainage (ARD) refers to the effluents from coal and metal mines. AMD is a common phenomenon which occurs naturally as a process of rock weathering, but is increased in large scale due to human activities such as construction contracts (transportation corridors, dam build, etc.) and mining operations. This phenomenon denotes the acidic water that is produced during exposure of sulphide minerals (mainly pyrite) to air and water through a natural process, and creates sulphuric acid. AMD is a hazard to animals, aquatic life and human beings as it increases the acidity and dissolves metals. Preventing and treating AMD is an important issue in a mine site not only during operation life but also after the mine is abandoned.
\end{abstract}

Keywords: acid mine drainage / acid rock drainage / tailings / mitigation

\section{MITIGACIÓN DEL DRENAJE ÁCIDO DE LAS MINAS: UNA REVISIÓN}

RESUMEN: El drenaje ácido de minas (AMD) o drenaje ácido de rocas (ARD) hace referencia a los efluentes de las minas de carbón y metal. El AMD es un fenómeno común que se produce naturalmente como un proceso de erosión de la roca, pero que aumenta en gran escala, debido a las actividades humanas como las construcciones (corredores de transporte, construcción de presas, etcétera) y las operaciones mineras. Este fenómeno denota el agua ácida que se produce durante la exposición de los minerales de sulfuro (principalmente pirita) al aire y al agua a través de un proceso natural, y crea ácido sulfúrico. El AMD es un peligro para los animales, la vida acuática y los seres humanos, ya que aumenta la acidez y disuelve los metales. La prevención y el tratamiento del AMD es una cuestión importante en una mina, no solo durante la vida de la operación sino también después de que la mina es abandonada.

Palabras clave: drenaje ácido de minas / drenaje ácido de rocas / colas / mitigación

*Correo electrónico: daniel.lazo@postgrad.curtin.edu.au 


\section{INTRODUCTION}

Historically, the acidic effluents from active and abandoned mines were called acid mine drainage (AMD). The term acid rock drainage (ARD) was used for the first time during the 1980 s and 90 s to denote acidic effluents from locations other than mines. In fact, ARD is the more generic name.

Mining-influenced water (MIW) is a term used for any water that has been affected in its chemical composition by mineral processing operations. MIW covers several different types of water such as residual waters, AMD waters, mineral processing waters and marginal waters (Wildeman and Schmiermund, 2004). The amount of AMD depends on several factors such as the mineralogy of the material, oxygen concentration, etc. and AMD occurs on a natural basis. Mining industries are the source of metals and economic activity, and AMD is a big concern for such industries. Mining operations tend to increase the amount of rock surface exposed to the atmospheric elements (air and water).

In addition, metal and coal deposits contain high levels of sulphide minerals (pyrite, pyrrhotite, chalcopyrite, chalcocite, etc.), which mostly react with water and oxygen, and generate acidic solutions. Elevated levels of heavy metals, acidity and salts have a negative influence on the surrounding area. AMD is acidic water which contains dissolved iron sulphite and other heavy metals with a pH less than 5 .

There are two main approaches for AMD treatment: passive and active treatment systems (Skousen et al., 1998; Wolkersdorfer, 2008). Both use different chemical, physical and biological methods to decrease the concentration of metals in AMD, but none has been successfully applied due to the different characteristics and chemistries of each mine site.

Currently, AMD needs to be treated at high expenditure before being discharged into the environment. This inhibits plant growth in the surrounding area of the mine site and avoids the successful reclamation of the mine site after the mine is abandoned. The main objective of AMD mitigation is to recover metals in the most convenient way for commercial and/or industrial utilisation.

There are several cases where mine drainage is not acidic and has dissolved metals in the solution. These mine drainages used to be acidic and have been neutralised in its streams through the discharge area. They are commonly named "neutral mine drainage" or "mining influence water".

\section{OCCURRENCE OF AMD NATURALLY}

AMD occurs when the sulphide minerals are exposed to the atmospheric elements: water and air. AMD detection is a powerful tool for exploration and thereby an important feature 
for mineral deposits. Exposed deposits will generally show a yellow-red layer due to oxide material known as gossan. Some examples are Río Tinto in Spain and Iron Creek in Colorado, which reflect the historical nature.

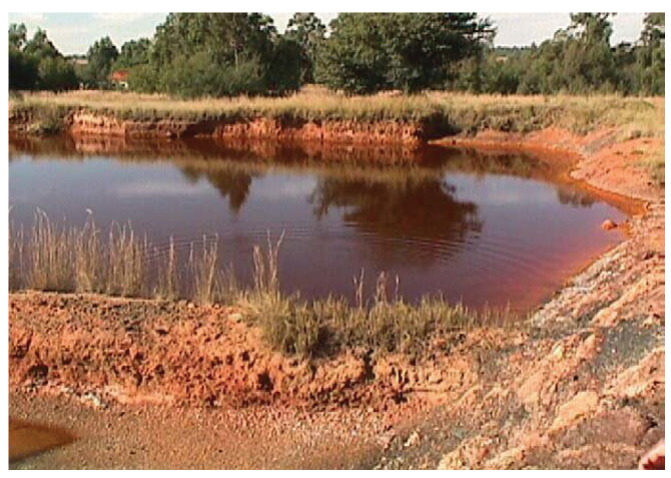

Figure 1. Example from an old metalliferous mine, South Africa

Source: Akcil and Koldas (2006)

The variables affecting AMD can be classified as:

- Primary: They are directly involved in the creation of sulphide oxidation reaction.

- Secondary: They influence the alteration and consumption of oxidation products.

- Tertiary: They are physical variables which affect the surrounding in the form of topography, climate, etc.

The AMD process is influenced by several variables:

- Microorganisms: The presence of some microorganisms strongly increase the AMD rate. Bacteria oxidises sulphur minerals as a source of energy. There are microorganisms which survive in sub-zero degree temperature, contributing to AMD in permafrost regions.

- Temperature: Higher temperatures accelerate the oxidation process. In the case of pyrite, oxidation occurs at $30^{\circ} \mathrm{C}$. For each 10-degree increase in temperature, the transformation rate doubles.

- Mineralogy: Each sulphide mineral oxidises at a different rate and neutralisation may occur with the presence of other minerals, which could decrease the production rate.

- Surface area exposed: Increasing the surface area of sulphide minerals accelerates the oxidation and creation of AMD due to exposure to the atmosphere. 
- Oxygen: AMD rates are accelerated in the presence of abundant oxygen, and formation rates of buried sulphide minerals are lower than those exposed to air.

- Water: Wetter areas produced higher rates than those areas where there was no water available. Thus, fresh mineral surface produces more oxidation due to the cycles of wetting and drying.

After being exposed to the atmosphere, metal sulphides start to oxidise (mainly pyrite, which is iron sulphide). Bacteria and archaea strongly increase the rate of decomposition of metal ions even in abiotic environments. These microorganisms, which have the ability to survive in harsh conditions, live naturally in the rock and keep in low number. Acidithiobacillus has an important and determinant role for pyrite oxidation.

Pyrite oxidation is a multistep reaction and an exothermic process (Skousen et al., 1998; Lottermoser, 2007). The chemistry of ferrous ion and ferric ions is complex and, due to this characteristic, it has inhibited a cost-effective treatment. A general equation can be described as follows:

$$
2 \mathrm{FeS}_{2(\mathrm{~s})}+7 \mathrm{O}_{2(\mathrm{~g})}+2 \mathrm{H}_{2} \mathrm{O}_{(\mathrm{l})} \rightarrow 2 \mathrm{Fe}_{(\mathrm{aq})}^{+2}+4 \mathrm{SO}_{4(\mathrm{aq})}^{-2}+4 \mathrm{H}_{\mathrm{aq}}^{+}+\text {energy }
$$

Next, oxidation of sulphide to sulphate solubilises ferrous iron (iron II), which is transformed to ferric iron (iron III). Ferric iron oxidises pyrite under acidic conditions. A general equation is shown below:

$$
4 \mathrm{Fe}_{(\mathrm{aq})}^{+2}+\mathrm{O}_{2(\mathrm{~g})}+4 \mathrm{H}_{(\mathrm{aq})}^{+} \rightarrow 4 \mathrm{Fe}_{(\mathrm{aq})}^{+3}+2 \mathrm{H}_{2} \mathrm{O}_{(\mathrm{l})}+\text { energy }
$$

Either of these reactions can be accelerated by bacteria, which generate energy from the oxidation and may occur suddenly. The ferric cations produced from the previous reaction oxidise new pyrite and the process goes on:

$$
\mathrm{FeS}_{2(\mathrm{~s})}+14 \mathrm{Fe}_{(\mathrm{aq})}^{+3}+8 \mathrm{H}_{2} \mathrm{O}_{(\mathrm{l})} \rightarrow 15 \mathrm{Fe}_{(\mathrm{aq})}^{+2}+2 \mathrm{SO}_{4(\mathrm{aq})}^{-2}+16 \mathrm{H}_{(\mathrm{aq})}^{+}
$$

All of these reactions generate an important effect which releases $\mathrm{H+}$, decreases the $\mathrm{pH}$ content and holds the solubility of the ferric ion:

$$
\mathrm{FeS}_{2}+\frac{15}{4} \mathrm{O}_{2}+\frac{7}{2} \mathrm{H}_{2} \mathrm{O} \rightarrow \mathrm{Fe}(\mathrm{OH})_{3}+2 \mathrm{SO}_{4}^{-2}+4 \mathrm{H}^{+}+\text {energy }
$$




\section{AMD: ENVIRONMENTAL IMPACT FROM MINING OPERATIONS}

AMD generates environmental damage that affects several countries with mining industries. Avoiding the creation or migration of AMD from its source is certainly considered the best choice. Sometimes it is not feasible in several locations: in that case, it is mandatory to compile, treat and discharge MIW.

Metal mine sites create highly acidic outflows when the ore is a sulphide mineral or is associated with pyrite. In these mines sites, the abundant metal ion may not be iron but other ones, such as nickel, copper or zinc. Copper mines are often responsible for AMD due to chalcopyrite, as it is a copper-iron-sulphide mineral.

There are several choices feasible to palliate AMD, which can be divided into either biological or chemical mechanisms that neutralise AMD to carry off metals from solution. Active treatment is a continuous process which requires extended input of resources to hold the process. Passive treatment is a process which requires a little amount of resources during the operation.

At several mine sites, AMD is not generated for several decades, whereas at other mines it is detected within 2-5 years. It is possible for decades or centuries to pass before the first sign of AMD. For this reason, AMD is a serious problem in the long-term perspective due to its influence on the environment.

The introduction of water in underground mining operations is the first step for generating AMD. Underground mining carries out its operations below the water table; therefore, water needs to be constantly pumped out in order to avoid flooding. When the lifetime of the mine is over, water floods the mine due to cease of the pumps. Furthermore, there are other structures which push the trigger of AMD, such as coal spoils, mine waste rock dumps and tailing piles or ponds.

Oxidation of sulphide minerals can have an upward trend by the effects of a group of bacteria called Acidophilus (e.g. Thiobacillus thiooxidans and Thiobacillus ferrooxidans). To generate acid drainage, the system is required to have water and oxygen. The bacteria use water as it serves as a reactant for the oxidation process and mode of transport. Oxygen sustains the bacteria and is a component in the chemical process. Sulphide oxidation finds the most outstanding conditions (moisture levels and unsaturated conditions) in tailing beds and mine-waste profiles.

AMD has the ability to affect the water quality by decreasing the $\mathrm{pH}$ and increasing the presence of dissolved metals in surface and groundwater. The grade of environmental impact on the water tables depends on the sensitivity and size of the water body affected. Likewise, it depends on the grade of dilution and neutralisation that occurs. Thereafter, AMD enters the groundwater, being able to have a negative impact on the 
health of plants, insects and aquatic animals. The dissolved metals in solution associated with AMD are often more prejudicial to aquatic animals.

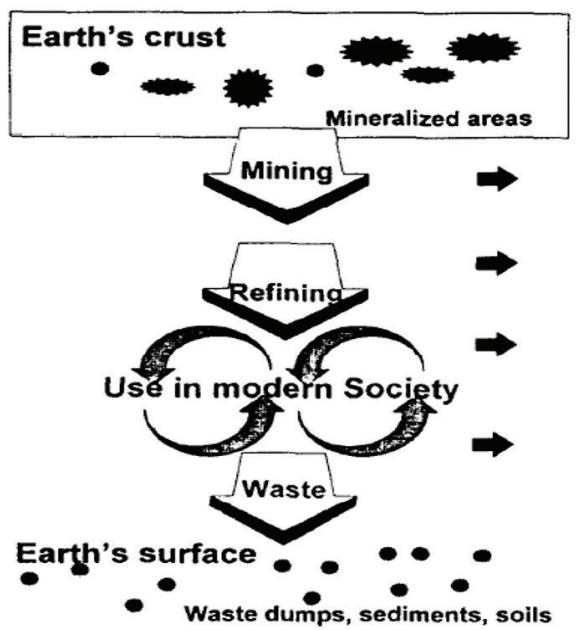

Figure 2. Pathway of metals from mineralised areas in the Earth's crust to their final "resting place" as diffuse pollutants in soils and sediments and stored in waste dumps

Source: Salomons (1995)

AMD can be produced in different areas of mine operations such as underground working drainage, open pit faces, waste rock/spoil dumps, ore stockpiles, tailing storage facilities and heap leach operations. In waste rock dumps, where the process commences immediately, acid generation occurs throughout the dump where there is high permeability to air and water. Tailing dumps have low permeability, and acid generation starts from top of the dam and moves slowly down (Browner, 2014).

Table 1

Table of sources of acid mine drainage

\begin{tabular}{ll}
\hline Primary Sources & Secondary Sources \\
Mine rock dumps & Treatment sludge pounds \\
Tailings impoundment & Rock cuts \\
Underground and open pit mine workings & Concentrated loadout \\
Pumped/nature-discharged underground water & Stockpiles \\
Diffuse seeps from replaced overburden in rehabilitated areas & Concentrate spills along roads \\
Construction rock used in road dams, etc. & Emergency ponds \\
\hline
\end{tabular}

Source: Akcil and Koldas (2006) 


\section{AVAILABLE METHODS FOR CONTROLLING AMD}

\subsection{Identification and prediction of AMD}

During the early development of a mine project to determine the potential for AMD, it is a common practice to carry out several evaluations. Data acquisition includes:

- Geological modelling

- Geological, geochemical, mineralogical, petrographic descriptions

- Geochemical assessment

- Use of software for oxygen movement and geochemical process

The geochemical assessment helps to determine the area of distribution and variability of important geochemical variables, leaching characteristic and acid generation.

The geochemical assessment includes the following steps:

1. Sampling

2. Static geochemical testing

3. Kinetics geochemical testing

4. Creating models for oxidation, pollutant generation

5. Creating models for material composition

Advances in AMD prediction include new software programs using algorithms, chemical assessment and acid-base accounting. Mining operations, which expose sulphide-bearing rocks, do not always create AMD due to the ore having huge amounts of acid-buffering minerals, i.e. bicarbonate or carbonate, calcite and lime, which are capable of diminishing or neutralising acidic waters. Neutralisation can be explained when baking soda (soda bicarbonate) is mixed with vinegar (weak acid): the baking soda reacts with the vinegar and the acid is neutralised. The prediction of AMD needs a whole understanding of the mineral characteristics, geological mapping, geochemical reactions, etc. because the composition of each ore is unique.

Mining companies must submit an evaluation of the AMD potential as future mines sites develop. Thus, they must supply detailed procedures to prevent or to supress the formation of AMD in mine sites at all phases of operation.

There are two practical methods to evaluate the possibility of having acid mine drainage (Browner, 2014):

A. Net acid-producing potential (NAPP): It measures sulphur content and calculates acid production. It also estimates how much sulphuric acid can be consumed 
to attack the ore. If acid production is greater than acid consumption, there is a problem of AMD.

B. Net acid generation (NAG): Mix the ore with hydrogen peroxide $\left(\mathrm{H}_{2} \mathrm{O}_{2}\right)$ and titrated acid is produced with sodium hydroxide. If more than $5 \mathrm{~kg}$ of sulphuric acid is produced per tonne, high acid-forming capacity is shown.

\subsection{Prevention of acid mine drainage}

The most cost-effective method to supress AMD is the prevention through foresight and mine planning. For example, mine design can be applied in a way that reduces the excavation of sulphide minerals. Several AMD strategies can be carried out if the sulphide mineral excavation is unavoidable.

- Covering waste rock: Wrapping the piles of waste rock with a layer of clay, plastic or soil negates contact with rain and oxygen to react with sulphide minerals. The main goal is to minimise the contact of water and have an oxygen barrier. Dry covers ought to hold erosion and provide support to vegetation. Several variables affect the design, such as waste material reactivity, type of waste material and climate conditions. To achieve long-term cover success, it is necessary to have a proactive detection and problem-solving attitude before any environmental impacts. Achieving this goal requires monitoring, repair, maintenance and contingency plans. Best environmental practice requires site-specific adaptation of local characteristics and environmental conditions.

- Mixing acid-buffering materials with acid-producing materials: Neutralisation of AMD can be achieved if there is a combination of limestone or calcite (acid-buffering material) and sulphide wastes (acid-producing materials).

- Storing underwater waste rock: Underwater storage is the most effective, cost-benefit and reliable method to prevent AMD. It reduces the rate of sulphide mineral oxidation by suppressing oxygen. The oxygen concentration in water is $8.6 \mathrm{mg} / \mathrm{L}$ at $25^{\circ} \mathrm{C}$, which is approximately 25,000 times lower than in the air. Several compounds and organic matter can decrease the dissolved oxygen in the water, which would not be available for sulphide oxidation. It is crucial to ensure that all material must be covered by at least 2 meters of water.

- Sealing and flooding underground mines: Sealing all the entrances in an underground mine avoids water flows in and out, which can produce water tables contamination. It means that the mine is isolated by sealing all the entrances.

- Treating sulphide wastes with chemicals: Organic chemicals have been used to eliminate sulphide oxidising bacteria to decrease the rate of AMD. There is a concern that these chemicals may eliminate beneficial bacteria. 
Preventive actions can achieve most effective outcomes when they are used in combination and adapted for each mine site. Furthermore, monitoring the groundwater and surface water would provide an early warning of AMD formation.

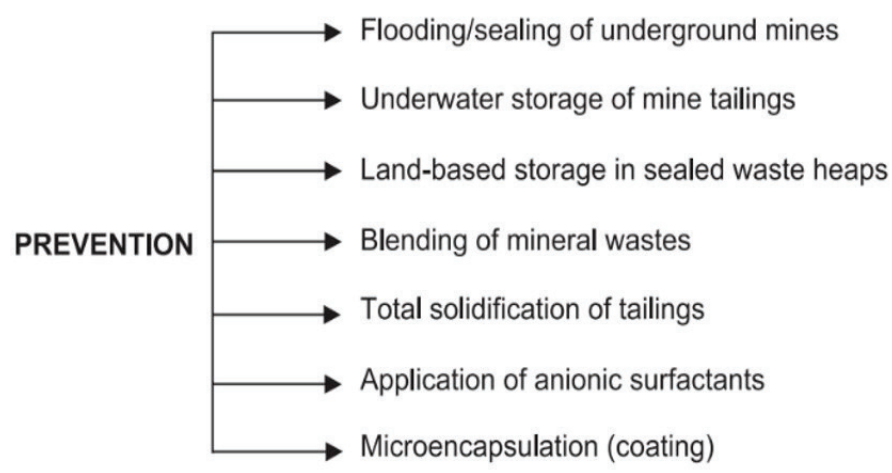

Figure 3. Various approaches that have been evaluated to prevent or minimise mine drainage waters

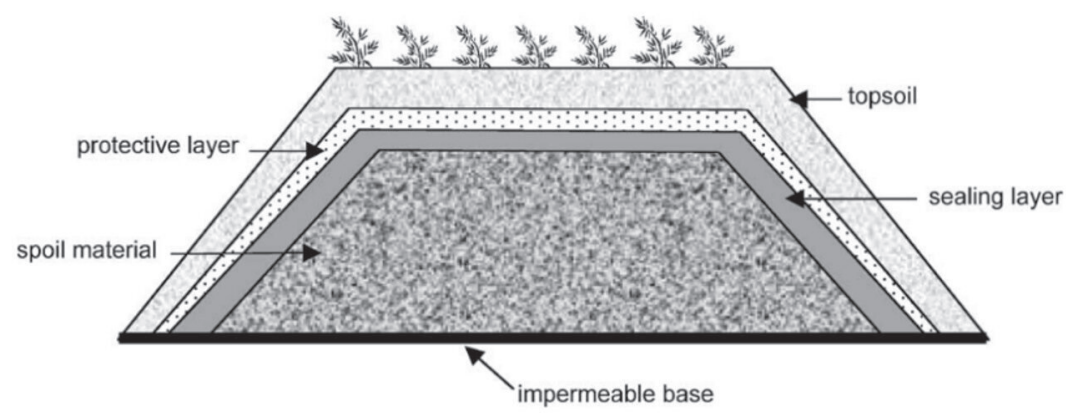

Figure 4. Layout of a "dry cover" for minimising production of mine spoil effluents

Source: Johnson and Hallberg (2004)

\subsection{AMD treatment: Conventional methods}

When the prevention strategy is unsuccessful for the formation of AMD, there are several methods to capture and treat AMD using water treatment processes. The most widespread method is adding an alkaline mineral (often lime) to the water. Although these methods show a high efficiency rate, they involve high material consumption and operating cost.

AMD treatment can be classified as passive and active (Johnson and Hallberg, 2004):

- Active treatments: They require continuous addition of chemical reagents and monitoring. 
- Passive treatment: They need little reagents, no reagents or no active monitoring.

There are several different methods to treat AMD after unsuccessful predictive and preventative methods. The most important methods are explained hereinbelow:

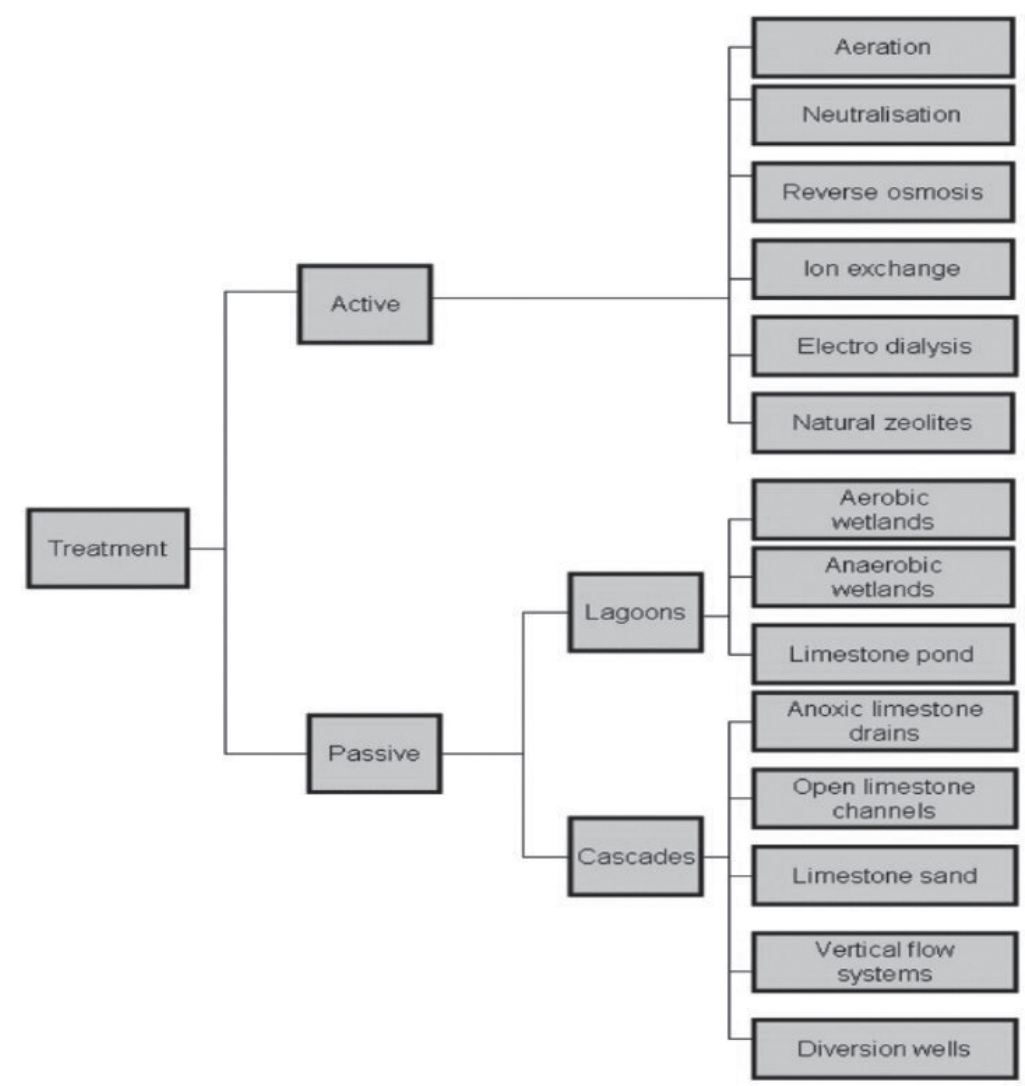

Figure 5. Flowchart of the available processes used for AMD treatment

Fuente: Ali (2011)

\subsubsection{Aeration}

According to Ackman and Kleinmann (1984), an in-line system is provided for treating AMD, which basically comprises the combination of a jet pump (or pumps) and a static mixer. The jet pump allows the entrance of air into the acid wastewater using a Venturi effect. Thus, it provides aeration of the wastewater, while further aeration is provided by the helical vanes of the static mixer. A neutralising agent is injected into the suction chamber of the jet pump and the static mixer is formed by plural sections offset by 90 degrees. Conventional AMD treatment processes basically comprise four steps: (1) neutralisation, (2) aeration, (3) settling and disposal of sludge, and (4) effluent discharge. 


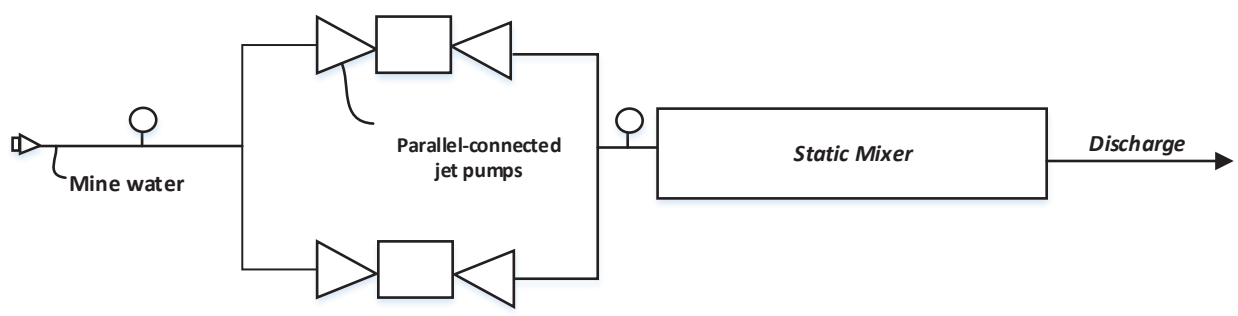

Figure 6. Se acid mine water aeration and treatment system

Source: Ackman and Kleinmann (1984)

\subsubsection{Neutralisation}

\section{Lime Neutralisation}

It is the most common and effective method for treating AMD, and it is used in highdensity sludge (HDS) process. In this method, slurry of limes is added to a tank, which is full of AMD and recycled sludge to increase water $\mathrm{pH}$ to 9. Most toxic metals change their properties and precipitate at $\mathrm{pH}$ 9. Also, air may be introduced to the chemical reaction to oxidise manganese and iron, and improve their precipitation. There are several variations of this process: it depends on the chemistry and volume of AMD, as well as other variables. Most of the time, the products of this process contain unreacted lime and gypsum, which affect the resistance to re-acidification.

Simple lime neutralisation may only need a mixing tank, lime silo and settling pond. This system is unbelievably cheap to build but it is less efficient, as it requires longer reaction times and the discharge has high metal concentrations. It is suitable for noncomplicated chemistry in AMD and low scale of streams.

\subsubsection{Reverse osmosis}

Osmosis occurs when two solutions, which have different concentrations but the same solvent, are separated by a semipermeable membrane. The solvent flows from the more dilute to the more concentrated solution (figure 7). This process continues until the two solutions reach the same concentration or the pressure on the more concentrated solution is increased to a value named the osmotic pressure. Whether a pressure over the osmotic pressure is applied on the more concentrated solution, the solvent can be flown into the more dilute solution. 


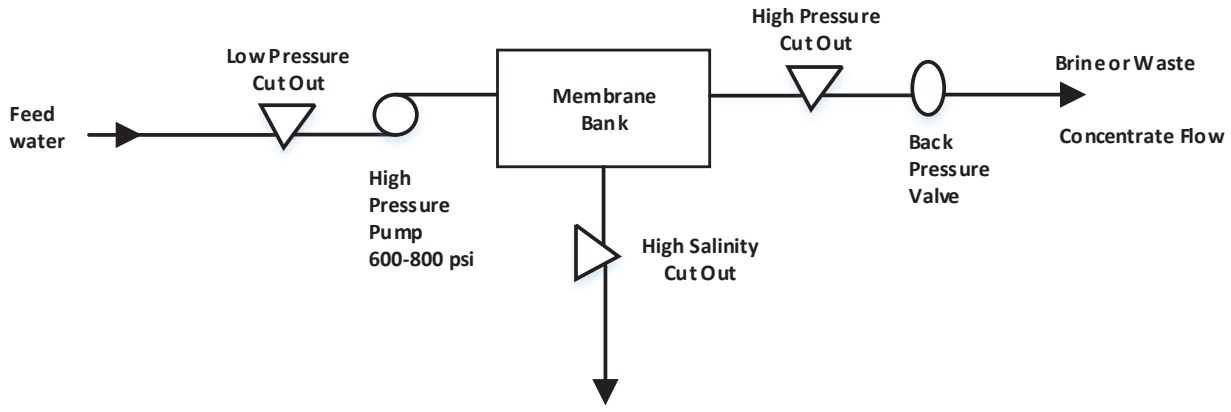

Figure 7. Essential elements of a reverse osmosis system

Source: Federal Water Quality Administration (1970)

\subsection{4 lon exchange}

The potential treatment for AMD has been researched based on the cation exchange process (figure 8). This technique is based on an ion-exchange resin, which can remove heavy metals (cationic resins) or sulphates, chlorides and sulphate complexes (anionic resins) from MIW. Figure 8 shows the use of weak-base resins (such as Amberlite IRA-68) operated in the bicarbonate cycle (Pollio and Kunin, 1967).

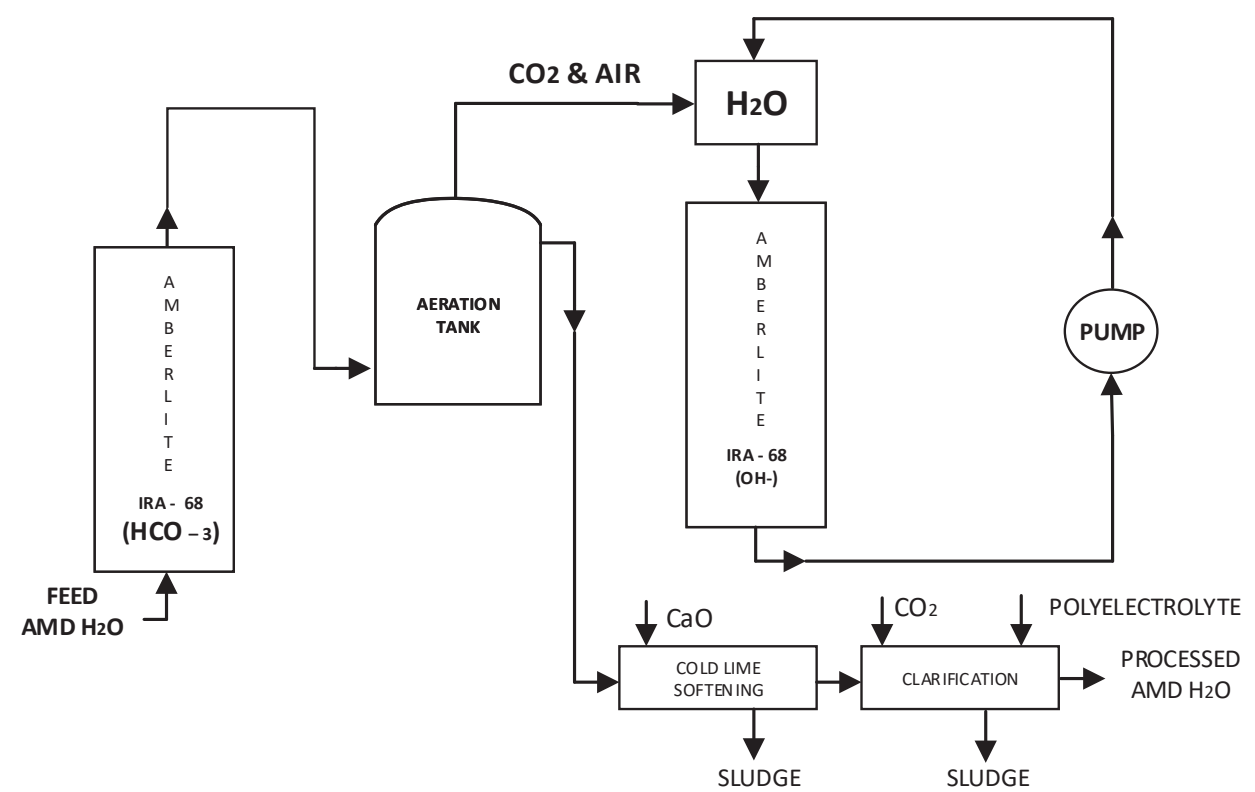

Figure 8. Ion exchange reclamation for AMD waters treatment

Source: Pollio and Kunin (1967) 


\subsubsection{Electrodialysis}

This method allows for the separation of metallic cations and anions; therefore, it achieves the target of removing metals and recovering water. The electrodialysis technique has shown to be an efficient method as it can remove more than $97 \%$ of the contaminants. The formation of precipitates of iron at the surface of the cation-exchange membrane may be a limiting problem of this technique by causing a blockage of the membrane (figure 9).

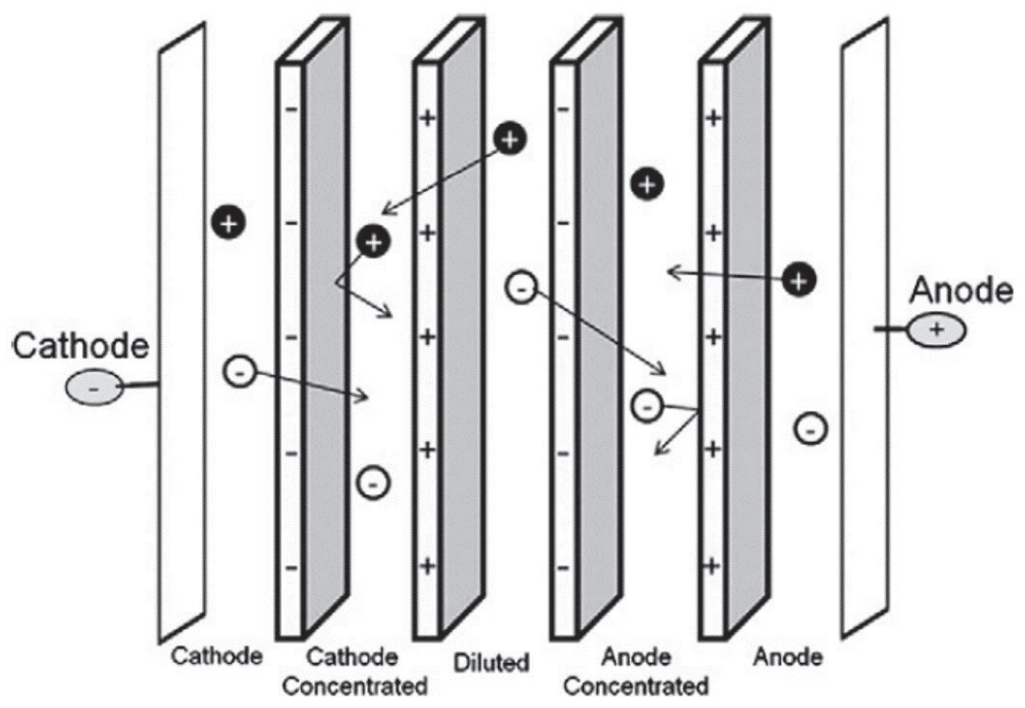

Figure 9. A schematic diagram of the ED process

Source: Cardoso et al. (2013)

\subsubsection{Natural zeolites}

Zeolites are natural alumina silicates with a three-dimensional framework structure bearing $\mathrm{AlO}_{4}$ and $\mathrm{SiO}_{4}$ tetrahedral where exchangeable cations are present and counterbalance the negative charge created by its isomorphous substitution (Barrer, 1978; Dyer, 1988). The natural properties of zeolite have gained much attention among researchers. These zeolites offer a combination of ion exchanges and molecular sieve, which can be easily modified (Cincotti et al., 2006).

Preliminary experiments showed that zeolites have the property to remove the heavy metals efficiently from dilute AMD. This natural mineral may be a substitute for other expensive reagents such as limestone, activated carbon, etc. due to its availability and low cost. Adsorption studies showed strong rates for the first 40 minutes and $80 \%$ removal. After this initial strong rate, the rate of adsorption decreases. 


\subsubsection{Constructed wetlands}

In the area of Eastern Appalachia, USA, this method has been developed during the 1980s to mitigate AMD generated by abandoned coal mines. Mostly, wetlands receive water which had been neutralised by limestone. At near neutral $\mathrm{pH}$, metal precipitation occurs from oxidation where carbonates or sulphides are recovered. Anaerobic bacteria are able to convert sulphate ions into sulphide ions. The most important advantage of this method relies on its relatively low cost. The limitation of this process is the metal loads it can deal with (high flows or metal concentrations). It is particularly important that wetland sediments remain all covered and permanently submerged. Aerobic wetlands use oxidation and hydrolysis reactions to treat mine water (Iribar et al., 2000). Figure 10 shows the physical and chemical process contributing to metal retention in wetlands.

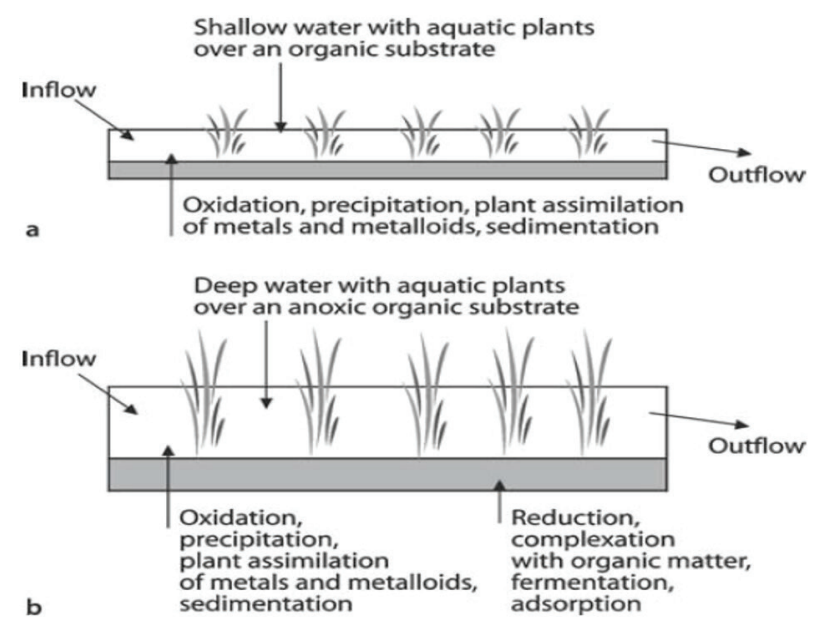

Figure 10. Generalised profiles of (a) aerobic and (b) anaerobic wetlands

Source: Younger et al. (2002)

\subsubsection{Limestone pond}

According to Skousen et al. (1995), a pond is constructed on the upwelling of an AMD seep or on an underground water discharge point (figure 11). Limestone is placed at the bottom of the pond and the water flows upward through the limestone. The pond needs to be designed to retain the water for one or two days. If some coating occurs, the limestone should be periodically stirred. More limestone needs to be added if it is exhausted by dissolution. 


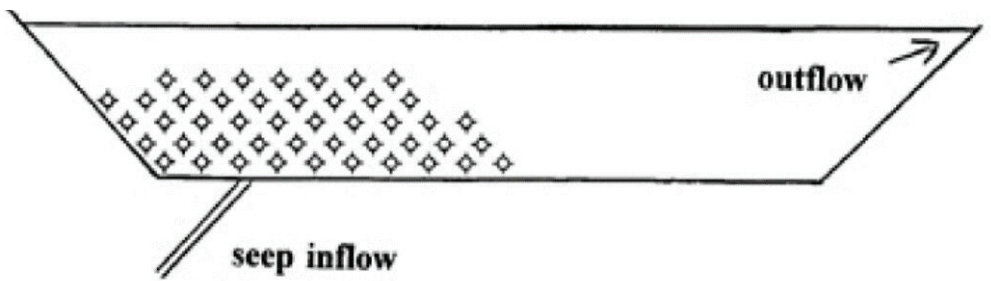

3-6 ft. Water

1-3 ft. Limestone

Figure 11. Limestone pond

Source: Skousen et al. (1995)

\subsubsection{Anoxic limestone drains (ALD)}

According to Lottermoser (2007), ALD consists of shallow trenches backfilled with crushed limestone, impermeable sediment and covered with plastic (figure 12). These trenches are sealed from the atmosphere to keep iron dissolved as $\mathrm{Fe}^{2+}$. This avoids oxidation of $\mathrm{Fe}^{2+}$ to $\mathrm{Fe}^{3+}$ and hydrolysis of $\mathrm{Fe}^{3+}$. The $\mathrm{pH}$ can be raised to neutral or alkaline levels. The effluence of anoxic limestone is frequently between $\mathrm{pH} 6$ and 7 .

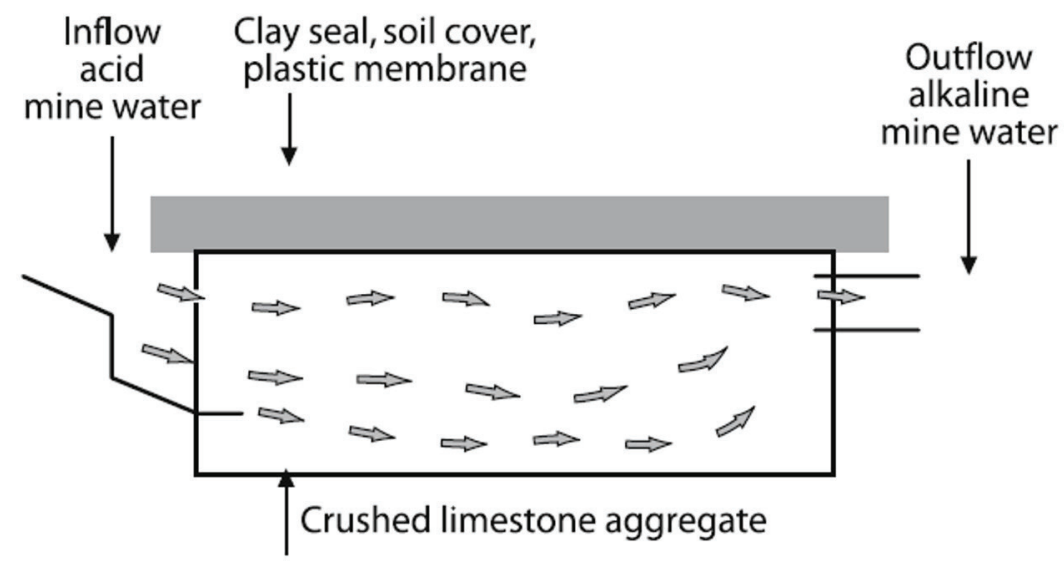

Figure 12. Schematic cross section of anoxic limestone drain

Source: Younger et al. (2002)

\subsubsection{Open limestone channels}

It is another passive treatment where a long channel of limestone can be used to carry acidic effluents to a stream or discharge point (figure 13). The channel can be designed with widths and heights, so the channel influences the amount of water to treat. Sloping 
the channel or channel configurations can help to reduce the sediment buildup. More limestone would be needed when the water causes armouring and reduces dissolution rate. From the graph below, small- or large-sized limestone is placed along the sides and bottom of culverts, ditches or stream channels.

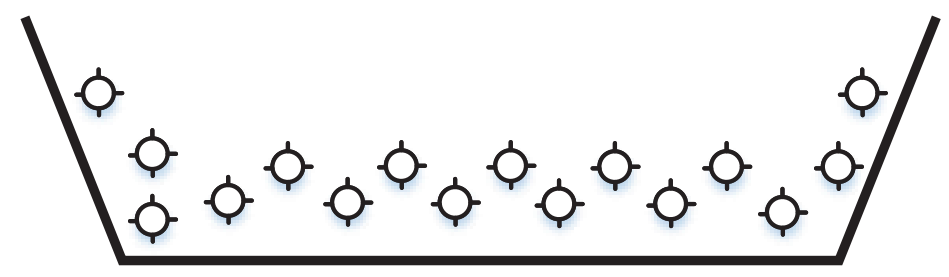

Figure 13. Open limestone channel

Source: Skousen et al., 1995

\subsubsection{Limestone sand}

Watten et al. (1999) designed and constructed a pulse limestone bed (PLB) process to increase the limestone dissolution rates and to avoid the accumulation of solids (figure 14). Water is introduced intermittently through nozzles into limestone sand reactors, which create a repeating cycle of fluidisation, bed turnover and contraction.

\subsubsection{Successive alkalinity-producing systems (SAPS)}

Alkalinity may be increased in "successive alkalinity-producing systems" where the effluent passed several vertically successive layers of organic matter (figure 15). There is an organic layer which reduces $\mathrm{Fe}^{+3}$ to $\mathrm{Fe}^{+2}$ and eliminates oxygen in the water. The reduced effluent enters an alkalinity layer of limestone and is discharged afterwards.

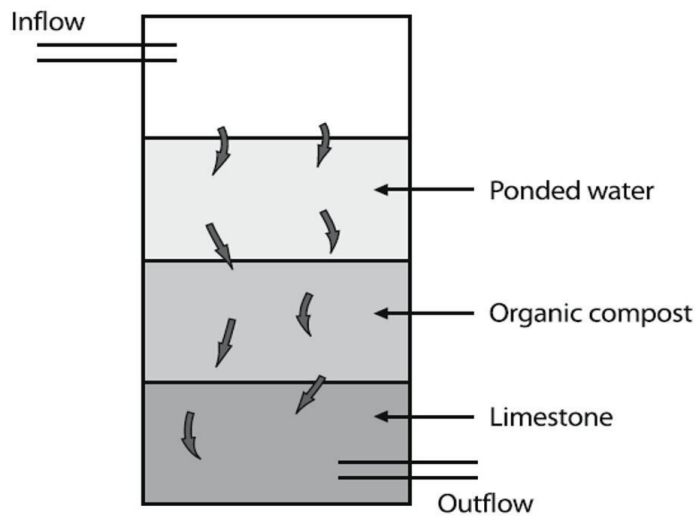

Figure 15. Schematic cross section of successive alkalinity-producing system Source: Brown et al., 2002 


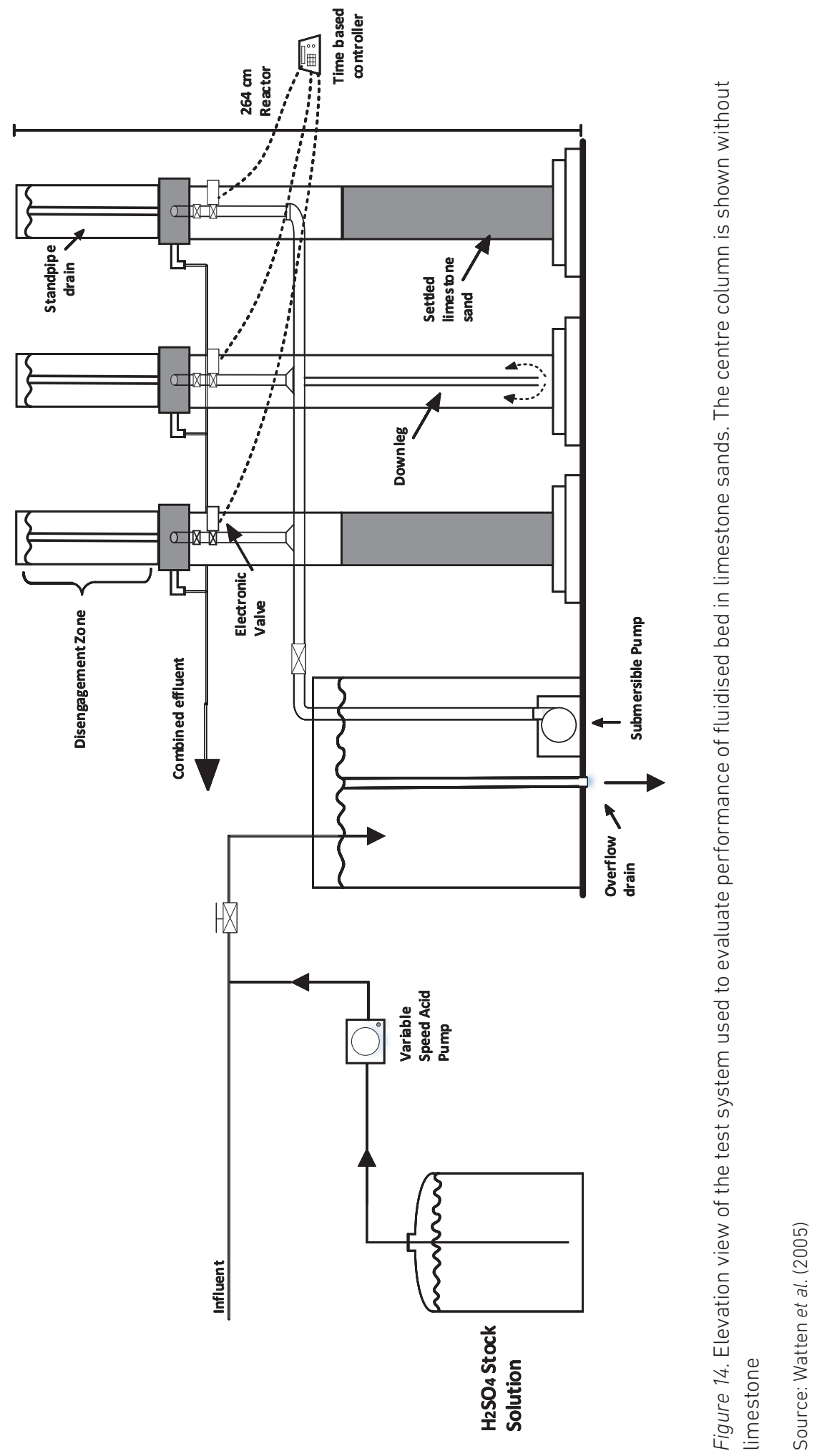




\subsubsection{Diversion wells}

A diversion well is a simple device and consists of a cylinder of metal. This well may be built in or besides a stream. A large pipe enters vertically down the centre. Water is fed into the pipe from an upstream dam. The water flows up through the well and the well is half full-on limestone gravel. The water fluidises the limestone, and the acidic water reacts and is neutralised (figure 16).

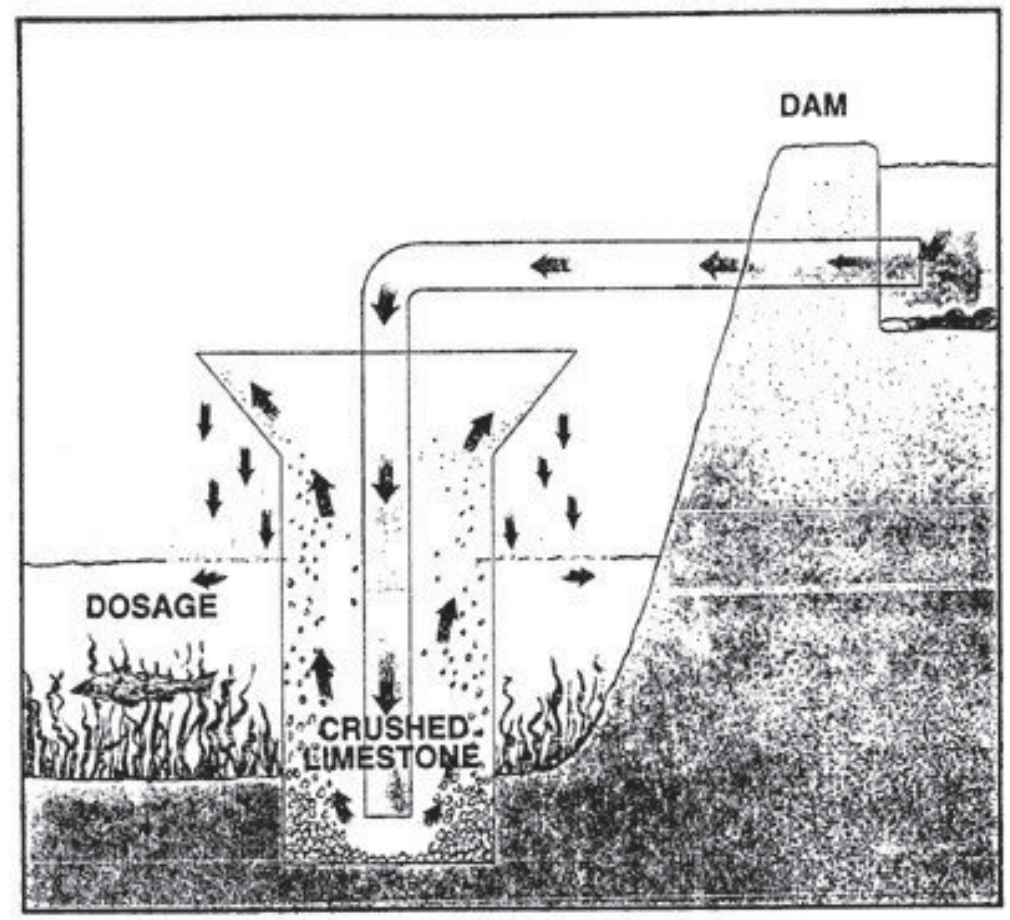

Figure 16. Schematic arrangement of a typical diversion well

Source: Arnold (1991)

\subsection{Treatments of AMD: New methods}

New technologies have been explored and passive treatment technologies to treat AMD have received interest because of low maintenance and operation cost. The most important technologies are described hereinbelow.

\subsubsection{Microbial fuel cell}

A metallurgical microbial fuel cell (MFC) is a new method for recovering copper from acid mine drainage. The copper is recovered in its metallic form at the cathode, while 
the energy, which is produced for metal reduction, can be recovered from the oxidation of organic material at the anode with possible generation of electric power (figure 17).

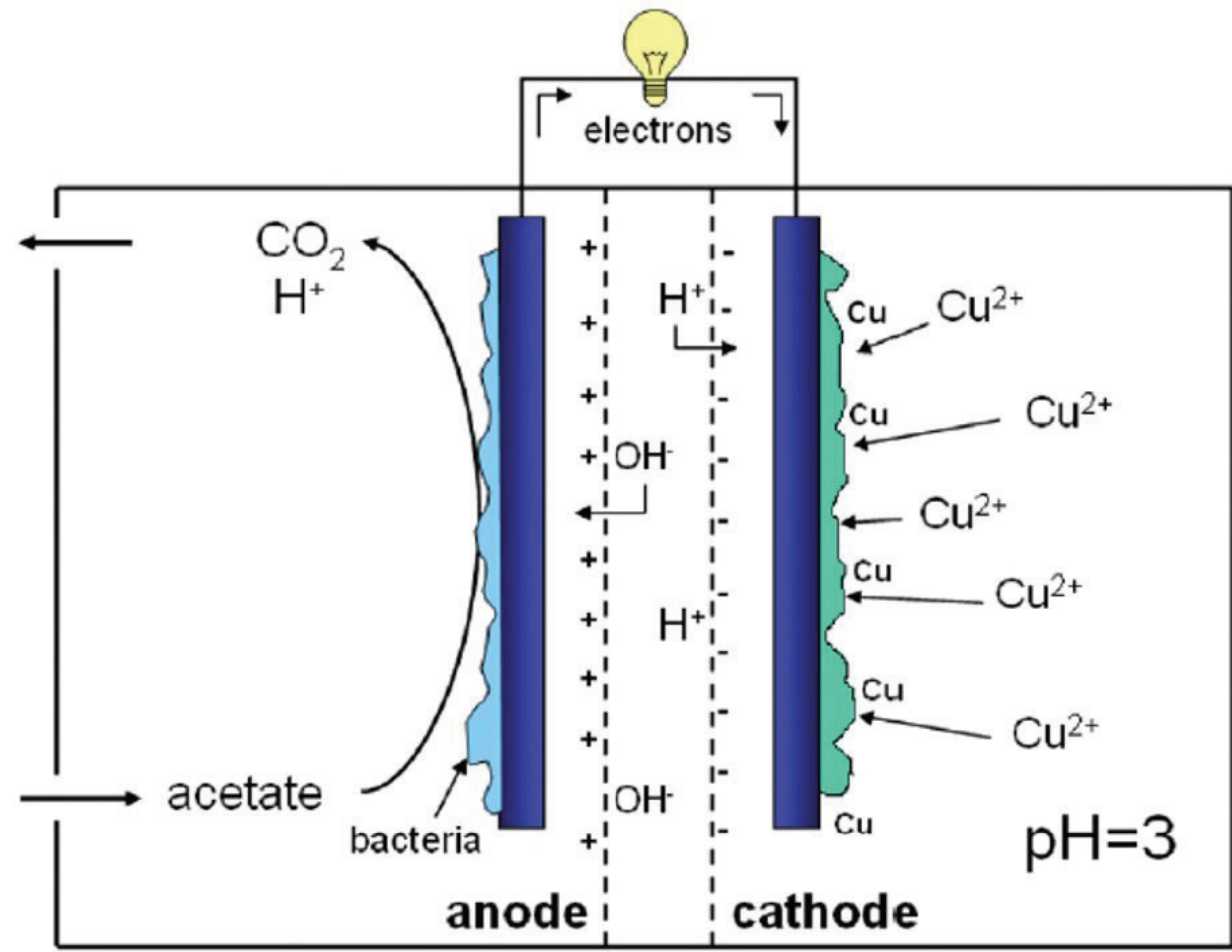

Bipolar membrane

Figure 17. Principle of the MFC with copper reduction and a bipolar membrane as a pH separator Source: Ter Heijne et al. (2010)

\subsubsection{Red mud bauxite residue}

Red mud bauxite (RMB) is a solution that is too alkaline to neutralise AMD. Screening tests showed that RMB has an outstanding capacity rate for a short time. Addition of brine increases its long-term capacity and leaching properties. Results have shown a neutral $\mathrm{pH}$ was held during the entire test for RMB and a mixture of RMB with brine. The presence of brine slightly lowered the $\mathrm{pH}$ compared to RMB alone. RMB alone lost its dissolved properties at the beginning of the test. Most of the alkalinity was lost after few flushes. The addition of brine keeps its neutralisation properties over several cycles of leaching. 


\section{CONCLUSIONS}

Acid mine drainage is a big concern during earth moving (road constructions, mining operations, etc.). Several approaches can be applied to avoid or mitigate AMD: prediction, prevention and treatment. Thus, the most cost-effective approach is prevention. When prevention methods fail, there are several conventional methods for AMD treatment. Lime neutralisation is the most extensively conventional method applied with some drawbacks. It is noteworthy to mention that the chemistry of each site is unique. For this reason, no method has been successfully applied worldwide. Moreover, environmental regulations are quite different in each region. Therefore, each region has its own environmental requirements for $\mathrm{AMD}$ mitigation.

- In general, each method needs to achieve the following objectives:

- Lowering the dissolved metal and sulphate concentration

- $\quad$ Raising the $\mathrm{pH}$

- Reducing the volume

- Decreasing the solution

\section{REFERENCES}

Ackman, T., Kleinmann, R. (1984). In-line aeration and treatment of acid mine drainage. Bureau of Mines Report of Investigations.

Akcil, A., Koldas, S. (2006). Acid Mine Drainage: causes, treatment and case studies. Journal of Cleaner Production, 14, 1139-1145.

Ali, M. (2011). Remediation of acid mine waters. Mine Water-Managing the Challenges.

Arnold, D. (1991). Diversion wells - a low cost approach to treatment of acid mine drainage. Twelfth Annual West Virginia Surface Mine Drainage Task Force Symposium.

Barrer, R., (1978). Zeolites and clay minerals as sorbents and molecular sieves. Chemie Ingenieur Technik, 50(4).

Brown, M. Barley, B., Wood, H. (2002). Minewater treatment: technology, application and policy. International Water Association Publishing.

Browner, R. (2014). Acid Mine Drainage class notes. Western Australia School of Mines. Curtin University, Australia.

Calatayud, M., Buzzi, D., García-Gabaldon, M., Ortega, M., Bernales, A., Tenorio, J., PérezHerraz, V. (2014). Sulphuric acid recovery from acid mine drainage by means electrodialysis. Desalination, 343, 120-127. 
Cardoso, D. Siqueira, M. Viegas, L. Bernardes, A. Soares, J. (2013). Water recovery from acid mine drainage by electrodialysis. Mineral Engineering, 40, 82-89.

Cincotti, A., Mameli, A., Locci, M.A., Orru, R., Cao, G. (2006). Heavy metal uptake by Sardinian natural zeolites: Experiment and modelling. Industrial and Engineering Chemistry Research, 45(3), 1074-1084.

Department of Mines and Petroleum, Western Australia (2009). Acid mine drainage.

Dyer, A. (1988). An introduction to zeolite molecular sieves. London: Wiley.

Falayi, T. and Ntuli, F. (2014). Removal of heavy metals and neutralization of acid mine drainage with un-activated attapulgite. Journal of Industrial and Engineering Chemistry, 20(4), 1285-1292.

Federal Water Quality Administration, US Department of Interior (1970). Treatment of acid mine drainage by reverse osmosis. Harrisburg, PA, USA.

Iribar, V., Izco, F., Tames, P. Antigüedad, I., Da Silva, A. (2000). Water contamination and remedial resources at the Troya abandoned Pb-Zn mine. Environmental Geology, $39,800-806$.

Johnson, D., Hallberg, K. (2004.) Acid mine drainage remediation options: review. Environmental Geology, 39, 800-806

Koldas, S. (2000). Notes of environmental inspection in South African Mines. Department of Minerals and Energy of South Africa. 125-126.

Lottermoser, B. (2007). Mine Wastes: Characterization, Treatment and Environmental Impacts. Springer Science and Business Media.

Luptakova, A., Ubaldini, S., Macingova, E., Fornani, P., Giuliano, V. (2012). Application of physical-chemical and biological-chemical methods for heavy metals removal from acid mine drainage. Process Biochemistry, 47(11), 1633-1639.

Motsi, T., Rowson, N.A., Simmons, M.J.H. (2009). Adsorption of heavy metals from acid mine drainage by natural zeolite. Int. J. Miner. Process, 92, 42-48.

Paradis, M., Duchesne, J., Lamontagne, A. Isabel, D. (2007). Long-term neutralisation potential of red mud bauxite with brine amendment for the neutralisation of acidic mine tailings. Applied Geochemistry, 22(11), 2326-2333.

Pollio, K. and Kunin, R. (1967). Ion exchange process for the reclamation of acid mine drainage waters. Environ. Sci. Technol, 1(3), 235-241.

Salomons, W. (1995). Environmental impact of metals derived from mining activities: Processes, predictions, prevention. Journal of Geochemical Exploration, 52(1-2), 5-23. 
Skousen, J., Faulkner B., Sterner, P. (1995). Passive treatment systems and improvement of water quality. West Virginia. Division of plant and soil sciences.

Skousen J., Rose, A., Geidel, G., Foreman, J., Evans, R., Hellier, W. (1998). A Handbook of technologies for avoidance and reclamation of acid drainage. National Mine Land Reclamation Center at West Virginia University. Morgantown, West Virginia.

Ter Heijne, A., Liu F., Van der Weijden R., Weijma, J., Buisman, C. and Hamelers, H. (2010). Copper recovery combined with electricity production in a microbial fuel cell. Environmental Science and Technology, 44(11), 4376-4381.

Walton-Day, K. (1997). Geochemistry of the processes that attenuate acid mine drainage in wetlands. Virginia: Geoscience World.

Watten, B., Sibrell, P. and Schwartz, M. (2005). Acid neutralization within limestone sand reactors receiving coal mine drainage. Environmental Pollution, 137(2), 295-304.

Watten, B.J. (1999). Process and apparatus for carbon dioxide pre-treatment and accelerated limestone dissolution for treatment of acidified water. U.S. Patent 5914046.

Wildeman, T. and Schmiermund, R. (2004). Mining Influenced waters: their chemistry and methods of treatment". Proceedings America Society of Mining and Reclamation, 2001-2013.

Wolkersdorfer, Ch. (2008). Water management at abandoned flooded underground mines. Water treatment. Berlin: Springer-Verlag Berlin Heidelberg.

Younger, P. L., Banwart S. A. and Hedin R. S. (2002). Mine water: hydrology, pollution, remediation. Dordrecht: Kluver Academic Publishers. 